Ingrid Fuglestvedt:

\title{
Rock Art and the Wild Mind - Visual Imagery in Mesolithic Northern Europe
}

\author{
Routledge, London \\ 2018, 437 sider, ISBN 978-1-138-09053-8
}

Boken omhandler bergkunst knyttet til det mesolittiske og nordlige Skandinavia, med hovedfokus på tre bergkunstområder: Vingen, Alta og Nämforsen. I tillegg til en grundig gjennomgang av dette materialet gir også forfatteren et innblikk i det mesolittiske samfunnet ved å se bergkunsten som en del av de sosiale prosessene i Nord-Europa innenfor denne tidsperioden. Boken er et resultat av det treårige forskningsprosjektet Meetings Make History (ledet av Ingrid Fuglestvedt og finansiert av Norges forskningsråd). Boken er et materialstudium som er sterkt teoretisk fundamentert.

Bokens struktur er oversiktlig og har en innledende del (prolog og kapittel 1-2, side147), hvor leseren settes inn i forfatterens grunnleggende tanker om hvordan bergkunstmaterialet kan sees i sammenheng med møter mellom mennesker, og hvordan det setter spor i den materielle kulturen. Bergkunstlokaliteter kan sees som rituelle plasser der mennesker møttes, og ritualer ble utført, der motivene viser relasjoner mellom dyr, mellom mennesker og mellom mennesker og dyr. I den første delen diskuteres også møtet mellom kultur og natur, og forfatteren setter det raskt i sammenheng med bergkunstens uttrykksform. Det mesolittiske materialet kan deles inn i to grupper, hvor det på den ene siden fremstilles dyrefigurer med høy grad av naturalisme (nature as it is) og på den annen side motiver med skjematiske og standardiserte mønstre (cultural products). Den første settes i sammenheng med den tidligste fasen, mens den mer skjematiske bergkunsten sees i sammenheng med den siste delen av mesolitikum og overgangen til neolitikum. Materialet viser noen regionale variasjoner i denne sammenheng. Denne todelingen har vært en del av skandinavisk bergkunstforskning i lang tid, men Fuglestvedt setter den i sammenheng med animistiske og totemistiske perspektiver, som gjennomgås grundig i del II av boken.

Materialet som inngår i denne boken, er såkalte veideristninger, arktiske ristninger og nordlig tradisjon ( hunters 'rock art), som tilhører perioden tidligmesolitikum til overgangen til tidligneolitikum - ca. 9500-3700 f.Kr. Størstedelen av materialet tilhører imidlertid 
perioden mellom senmesolitikum og tidligneolitikum, og det er bergkunstlokalitetene i Vingen, Alta og Nämforsen som er hovedfokuset (Gjerde 2010; Lødøen og Mandt 2012; Helskog 2014). Dateringene forfatteren bruker i sin materialgjennomgang i tabell 2.1 (side 25), er det som beskrives som dateringsforslag og hun refererer til radiokarbonalder eller strandlinjer og hvor de er hentet fra. Fuglestvedt har ingen større diskusjon knyttet til bruken av dateringsmetodene.

Videre er boken delt inn i tre deler som bygger logisk på hverandre. I del I (kapittel 3-6, side 49-250) settes leseren inn i forfatterens relasjon til Claude Lévi-Strauss (blant annet 1966, 1978), og vi blir introdusert for begreper som wild mind og mythical thinking. Når det gjelder det teoretiske rammeverket for denne boken, er det svært solid, og jeg kan på ingen måte utfordre denne delen av boken. Det er tydelig at forfatteren har en dybdekunnskap som hun anvender og tilpasser sitt materiale, og som brukes gjennomgående i alle deler av boken. Kapittel 3 kan oppleves som den tyngre delen av boken, men gjennom grundig eksemplifisering ledes leseren inn i forfatterens tankegang. Vi introduseres for begrepet The myth, som brukes som et tankemessig verktøy for å kunne forstå verden, og mythemes representerer slik de minste bestanddelene av dem, som kun gir mening gjennom konteksten. Videre blir vi så introdusert for begrepet moteme som forfatteren ser på som den minste motivenheten av den nordiske veidekunstens signifikans. Disse motemene representerer på denne måten en større struktur, både som hele bergkunstpaneler eller deler av panelet. Forfatteren har gjennom dette klart å identifisere ulike nøkkelmotemer (key motemes) i materialet som er variasjoner rundt hjortedyrmotiv, den største motivgruppen innenfor veideristningstradisjonen. I hovedsak deler forfatteren dem i to: enslige, store hjortedyr eller flokker av hjortedyr (vilt). Det første nøkkelmotemet kan sees gjennom hele mesolitikum, det siste kommer i bruk i samme periode som de store bergkunstfeltene i Vingen, Alta, Nämforsen og Øst-Norge.

Gjennom denne motivgjennomgangen kommer også forfatteren med nye tolkninger av kjente motiver, som for eksempel ulike rammefigurer og geometriske figurer. Dem setter hun i sammenheng med menneskelige samfunn, hvor hun for eksempel tolker rammefigurer/gjerder (side 144) som stiliserte mennesker forbundet i rekker. Dette er mønstre vi finner igjen flere steder, både i Alta, Telemark, Trøndelag og Vingen. De ulike motemene (sammenfattet i illustrasjonen 4.52 på side 161) kan gjenkjennes, og forfatteren eksemplifiserer likheter og variasjoner innenfor de ulike områdene. Denne delen av boken finner jeg meget interessant, og den bringer noe nytt til materialet på en inspirerende måte. Indre mønstre er elementer som også tidligere har vært gjenstand for fascinasjon, og har vært analysert i ulike sammenhenger, men Fuglestvedt bringer nye perspektiver til hvordan de kan tolkes i sammenheng med samfunnsorganisering, og ser sammenhenger på tvers av større geografiske områder.

I del II av boken (kapittel 7-10, side 253-350) analyseres tilstedeværelse og fravær av indre mønstre i sammenheng med animisme og totemisme. Det gis innledningsvis en grundig innføring i de teoretiske retningene, før forfatteren spisser og konkretiserer dem inn mot sitt materiale. Fuglestvedt knytter det ytre fokuset (fravær av indre mønstre) til animisme, som igjen knyttes til den eldste fasen, hvor de ønsket å fremstille dyr slik de fremstår i naturen. Det indre fokuset (indre mønster) settes derimot i sammenheng med totemisme, som kan indikere ulike klanlandskaper (figur 9.9, side 335) som vises i bergkunstmaterialet fra senmesolitikum. Fuglestvedt ser bergkunstfeltene som representasjoner av klanterritorier, 
enten plassert i hjertet av territoriene eller i grensesoner, hvor hun skisserer mulige kontaktlinjer mellom de ulike områdene (figur 10.9, side 349). Det finnes usikkerhetsmomenter ved en slik analyse, slik forfatteren selv påpeker, og det vil være elementer i bergkunsten som kan forstås på en annen måte. Samtidig viser forfatteren til flere gode eksempler (kapittel 9 og 10) som kan støtte en slik analyse og ideen om et mulig felles mesolittisk tankesett.

I del III og siste del av boken (kapittel 11-12, side 353-401) ser Fuglestvedt nærmere på aspekter som kjønn og gaveutveksling. I sin gjennomgang finner hun svært få markeringer av kjønn og avbildninger av menneskefigurer i Alta, Vingen og Nämforsen. Imidlertid kan gjenstander som for eksempel økser knyttes til menn (tolket som gravfunn). Det kan vitne om at menn og kvinner har hatt ulik deltagelse i ulike ritualer. Totemisme og klanlandskapet kan settes i sammenheng med hvorfor også statusgjenstander (som for eksempel økser) øker i antall og kan sees som symbolske gaver. Denne økningen kan sees som en generell økning av rituell aktivitet - også økningen av bergkunst.

Det er vanskelig å gi en kort fremstilling av en slik bok, og det vil alltid være andre aspekter som kunne ha vært trukket frem. Jeg ønsker først å berømme Fuglestvedt for det arbeidet som ligger bak en slik monografi. Dette er et stort arbeid og et dypdykk i et spennende materiale hvor hennes nye perspektiver er svært inspirerende å lese. Gjennom å skrive en monografi får forfatteren større rom for både å gå i dybden av den retningen hun ønsker, og det gir leseren mer rom for å forstå de ulike lagene av teksten og analysen. Deler av boken har en teoretisk dybde som gjør at leseren trenger presiseringer og eksemplifiseringer for å forstå sammenhengen, og det er også her bokens struktur virkelig er en styrke. Forfatteren tar med seg videre de sentrale begrepene og de teoretiske perspektivene, som hun igjen bygger videre på i analysene i de neste kapitlene.

I tillegg til sine tre undersøkelsesområder trekker også Fuglestvedt inn annet materiale, for eksempel flere kjente felt fra Midt-Norge. Forfatteren skriver at det tidligmesolittiske materialet er mer homogent, og er realistisk avbildet (full størrelse, konturtegnet), og hun trekker inn materiale fra blant annet Bøla og Bardal i Trøndelag. Dersom man anvender strandlinjedatering på det midtnorske materialet, finnes det eldre felt enn disse på Fosenhalvøya. Dette er malerifelt (som for eksempel Mølnargården, Varghiet og Gjølga), som har en maksimumsalder på 8200-8800 BP, og er de eldste feltene i Midt-Norge dersom strandlinjedatering er en riktig metode å bruke på dette materialet (metoden er senere kritisk gjennomgått (Stebergløkken 2016; Sognnes 2017; Stebergløkken 2017)). Disse feltene har imidlertid et uttrykk som er mer skjematisk, og flere av elgmotivene har indre mønster, et fenomen som forfatteren knytter til senmesolittisk kontekst. Forfatteren har utelatt dette materialet fra det midtnorske materialet som er omtalt (tabell 2.1), og det savner jeg, spesielt med tanke på den videre diskusjonen. Fuglestvedt har gode argumenter for sine geografiske avgrensninger, og det er som sagt Vingen, Alta og Nämforsen som har hovedfokus i denne boken. Det er kanskje min egen nysgjerrighet på om dette materialet faktisk skiller seg ut, eller om det er andre årsaker som ligger bak, som gjør at jeg savner det utelatte materialet. Det viser likevel muligheten for videreføring av analysearbeidet til andre bergkunstområder.

Jeg har stor tro på at man trenger både mikroperspektivet (tegnemåte/konstruksjon) og makroperspektivet (landskap og kulturhistorisk kontekst) for å nærme seg bergkunsten. Dette er en klar styrke ved boken: hvordan detaljene i tegnemåten opptrer eller er fraværende, tilstedeværelse av ulike elementer, og hvordan bergkunsten settes i sammenheng med den øvrige konteksten. Gjennom å relatere bergkunsten til diskusjoner knyttet til kjønn, 
nettverk og alliansebygging hos jeger- og sankergrupper settes bergkunsten inn i en større kontekst. Boken er et viktig bidrag både til bergkunstforskningen og til forskningen forøvrig, og jeg kan varmt anbefale den.

\section{Litteratur}

Gjerde, Jan Magne

2010 Rock art and Landscapes. Studies of Stone Age rock art from Northern Fennoscandia. Universitetet i Tromsø, Tromsø.

Helskog, Knut Arne

2014 Communicating with the world of beings: the World Heritage rock art sites in Alta, Arctic Norway. Oversatt av Tim Challman. Oxbow Books, Oxford.

Lévi-Strauss, Claude

1966 The Savage Mind. The University of Chicago Press, Chicago.

1978 Myth and Meaning: Cracking the Code for Culture. Routledge \& Kegan Paul, London.

Lødøen, Trond Klungseth og Gro Mandt

2012 Vingen: et naturens kolossalmuseum for helleristninger. Instituttet for sammenlignende kulturforskning, Serie B, vol. 146. Akademika, Trondheim.

Sognnes, Kalle

2017 The northern rock art tradition in central Norway. BAR International Series 2837. BAR Publishing, Oxford.

Stebergløkken, Heidrun

2016 Bergkunstens gestalter, typer og stiler: En metodisk og empirisk tilncerming til veidekunstens konstruksjonsmåter $i$ et midtnorsk perspektiv. Doktoravhandlinger ved NTNU, 2016(38). Det humanistiske fakultet. Institutt for historiske studier. NTNU Grafisk senter, Trondheim.

2017 Where Styles Meet - What Does it Mean? I North Meets South - Theoretical aspects on the northern and southern rock art traditions in Scandinavia, redigert av Peter Skoglund, Johan Ling og Ulf Bertilsson, s. 35-58. Swedish Rock Art Series, vol. 6. Oxbow books, Oxford. 